\title{
PENGARUH SENAM NIFAS TERHADAP INVOLUSI UTERUS DAN PENGELUARAN LOKIA DI WILAYAH KERJA PUSKESMAS CILEMBANG KOTA TASIKMALAYA TAHUN 2015
}

\author{
Etin Rohmatin \\ Dosen Jurusan Kebidanan Poltekkes Kemenkes Tasikmalaya
}

\begin{abstract}
ABSTRAK
Tujuan penelitian ini untuk mengetahui pengaruh senam nifas terhadap involusi uterus dan pengeluaran lokia. Metode yang digunakan dalam penelitian ini adalah metode analitik dengan pendekatan atau rancangan pra eksperimen Populasi dalam penelitian ini adalah ibu nifas di Puskesmas Cilembang yang melahirkan bulan September-November Tahun 2015 yaitu 32 orang dengan teknik pengambilan sampel total sampling. Hasil penelitian menunjukkan bahwa 32 ibu nifas yang diintervensi senam nifas yang mengalami involusi uterus normal yaitu 24 orang $(75 \%)$, pengeluaran lokia normal yaitu 23 orang $(71,9 \%)$. Hasil uji statistik dengan menngunakan chi-square senam nifas terhadap involusi uterus $\rho=0,005$ lebih kecil dari 0,05 dan terhadap pengeluaran lokia $\rho=0,013$ lebih kecil dari 0,05. Kesimpulan dari penelitian ini ada pengaruh senam nifas terhadap involusi uterus dan pengeluaran lokia.
\end{abstract}

Kata Kunci : Senam Nifas

\begin{abstract}
The purpose of this research was to determine the effect of the postpartum exercise towards uterine involution and lochia charge. The method used in this research was analytic with pre experiment one-group post test only design. The Population in this research was 25 post partum women during 2015 as sun 32 women as total sampling. The results showed that 32 puerperal women who were experiencing postpartum exercise had normal uterine involution as many as 24 people (75\%) and normal lochia discharge as may as 23 people ( $71.9 \%$ ). Statistical test result $\rho=0,005$. The conclusion of this study has effect on uterine involution postpartum gymnastics and spending lochia.
\end{abstract}

Keywords : Post partum exercise

\section{PENDAHULUAN}

Hasil penelitian menunjukan bahwa $60 \%$ kematian ibu akibat kehamilan terjadi setelah persalinan, dengan $50 \%$ kematian nifas terjadi dalam 24 jam pertama (Bobak, 2004). Salah satu penyebab kematian masa nifas diakibatkan infeksi masa nifas, karena kurangnya mobilisasi ibu post partum (Bobak, 2004).

Hasil penelitian yang dilakukan oleh Tambunan (2009) tentang pengaruh ambulasi dini terhadap involusi uterus di Klinik Bersalin
Hadijah Medan Tahun 2009 didapatkan hasil bahwa senam nifas mempengaruhi involusi uterus dengan nilai $p=0,000$.

Penelitian yang dilakukan oleh Agung (2008), pada hari ke-3 lokia sanguilenta ditemukan pada ibu post partum yang melakukan senam nifas sebanyak $80 \%$ sedangkan yang tidak melakukan senam nifas sebanyak $60 \%$.

Berdasarkan pengamatan pada studi pendahuluan di BPM Ny. L Kota Tasikmalaya 
dari bulan Mei-Juli 2015 terdapat ibu postpartum sebanyak 18 orang, yang melakukan senam nifas sebanyak 6 orang dan tidak senam nifas sebanyak 12 orang. Hasil studi pendahuluan menunjukkan 5 orang $(83 \%)$ ibu nifas yang melakukan senam nifas pada hari ke 10 uterus sudah tidak teraba sedangkan yang tidak melakukan

\section{METODE PENELITIAN}

Metode yang digunakan dalam penelitian ini adalah metode analitik dengan pendekatan pre experiment dengan post test only design one group. Metode tersebut digunakan karena peneliti ingin mengetahui pengaruh senam nifas terhadap involusi uterus dan pengeluaran lokia

Populasi dalam penelitian ini adalah ibu nifas di 2 BPM yang ada di wilayah kerja Puskesmas Cilembang yang taksiran partusnya pada bulan Oktober - November Tahun 2015. Teknik pengambilan sampel pada penelitian ini adalah dengan menggunakan teknik Total Sampling yaitu pengambilan semua ibu yang melahirkan normal pada bulan Oktober - November 2015.

Penelitian ini dilakukan pada bulan September-November 2015 untuk mendapatkan data senam nifas, involusi uteri dan pengeluaran lokia. Pelaksanaan pengumpulan data dilakukan oleh peneliti dan dibantu oleh 2 orang bidan sebagi enumerator yang bertugas di Wilayah Kerja Puskesmas Cilembang Kota Tasikmalaya, Persamaan persepsi dilakukan dengan cara masing - masing orang melakukan gerakan senam nifas lalu yang lain menilai dengan daftar tilik dan diuji dengan uji kappa. Hasil uji

\section{HASIL PENELITIAN.}

Penelitian dilakukan di wilayah kerja Puskesmas Cilembang Kota Tasikmalaya bertempat di BPM $L$ dan E karena dari kedua tempat praktek ini sudah mencukupi jumlah sampel yang dibutuhkan. Berikut ini akan senam nifas pada hari ke 10,8 orang mengalami keterlambatan involusi/ sub involusi. Hasil tersebut menunjukkan ada juga ibu nifas yang melakukan senam nifas tetapi tetap mengalami sub involusi sebanyak 1 orang $(17 \%)$ dan pengeluaran lokia yang tidak sesuai sebanyak 1 orang $(17 \%)$

persepsi menggunakan uji kappa menunjukkan bahwa seluruh numerator memiliki nilai signifikan kurang dari 0,05.

Data diolah melalui tahapan editing (edit data), coding (pengkodean), entry (input data) dan tabulating (menghitung).

Analisis univariat dilakukan untuk mendeskripsikan senam nifas, involusi uterus dan pengeluaran lokia. Analisis bivariat pada penelitian ini adalah menggunakan Analisis Uji Chi Square satu sampel dengan rumus menurut Sugiyono (2006) :

$$
\chi^{2}=\sum_{i=1}^{K} \frac{\left(f_{0}-f_{h}\right)^{2}}{f_{n}}
$$

$\chi^{2}=$ Chi Kuadrat

$\mathrm{f}_{\mathrm{o}}=$ Frekuensi yang diobservasi

$f_{n}=$ Frekuensi yang diharapkan

Responden diberi penjelasan terkait penelitian yang akan dilakukan, kemudian responden menandatangani informed consent setelah mendapatkan penjelasan dari peneliti. Responden boleh menolak atau menyetujui penelitian yang akan dilakukan. Data terkait responden dijaga kerahasiannya.

diuraikan hasil penelitian mengenai rangsangan senam nifas, involusi uteri, pengeluaran lokia dan pengaruh senam nifas terhadap involusi uteri serta terhadap pengeluaran lokia. 
1. Gambaran involusi uterus yang melakukan senam nifas di wilayah kerja Puskesmas Cilembang Kota Tasikmalaya.

Tabel 1. Distribusi Frekuensi Responden Berdasakan Involusi Uterus Setelah Melakukan Senam Nifas

\begin{tabular}{ccc}
\hline Involusi Uterus & N & $\%$ \\
\hline Normal & 24 & 75 \\
\hline Tidak Normal & 8 & 25 \\
\hline Jumlah & $\mathbf{3 2}$ & $\mathbf{1 0 0 , 0}$ \\
\hline
\end{tabular}

Dapat dilihat bahwa keadaan involusi uterus pada ibu yang melakukan senam nifas berkategori normal sebanyak 24 orang $(75 \%)$ dan yang tidak normal involusi uterusnya sebanyak 8 orang $(25 \%)$.

2. Gambaran pengeluaran lokia yang melakukan senam nifas di Wilayah Kerja Puskesmas Cilembang Kota Tasikmalaya

Tabel 2. Distribusi Frekuensi Responden Berdasarkan Pengeluaran Lokia Setelah Melakukan Senam Nifas

\begin{tabular}{ccc}
\hline Pengeluaran Lokia & N & $\%$ \\
\hline Normal & 23 & 71,9 \\
\hline Tidak Normal & 9 & 28,1 \\
\hline Jumlah & $\mathbf{3 2}$ & $\mathbf{1 0 0 , 0}$ \\
\hline
\end{tabular}

Dapat dilihat bahwa pengeluaran lokia pada ibu yang melakukan senam nifas berkategori normal sebanyak 23 orang $(71,9 \%)$ dan yang tidak normal pengeluaran lokianya sebanyak 9 orang $(28,1 \%)$

3. Pengaruh senam nifas terhadap involusi uterus

Tabel 3. Pengaruh Senam Nifas Terhadap Involusi Uterus

\begin{tabular}{ccccc}
\hline Involusi Uterus & $\mathbf{F}$ & $\%$ & $\chi^{2}$ & $\rho$ value \\
\cline { 1 - 3 } Normal & 24 & 75 & & \\
\cline { 1 - 3 } Tidak Normal & 8 & 25 & & 0.000 \\
\hline Total & 32 & 100,0 & & \\
\hline
\end{tabular}

Dapat dilihat bahwa ibu nifas yang melakukan senam nifas dengan involusi uterus normal sebanyak 24 orang dan involusi uterus tidak normal sebanyak 8 orang. Uji statistik chi square dengan tingkat ketelitian 0,05 menunjukkan nilai $\chi^{2}$ sebesar 8,00 dengan $\rho$ value sebesar $0,005<0,05$ artinya Ho ditolak dan Ha diterima. Hal ini menunjukkan ada pengaruh senam nifas terhadap involusi uterus di wilayah Kerja Puskesmas Cilembang Kota Tasikmalaya. 
4. Pengaruh senam nifas terhadap pengeluaran lokia

Tabel 4. Pengaruh Senam Nifas Terhadap Pengeluaran Lokia

\begin{tabular}{ccccc}
\hline Pengeluaran Lokia & F & $\%$ & $\chi^{2}$ & $\rho$ value \\
\hline Normal & 23 & 71,9 & & \\
\cline { 1 - 3 } Tidak Normal & 9 & 28,1 & 6,125 & 0.013 \\
\cline { 1 - 3 } Total & 32 & 100,0 & & \\
\hline
\end{tabular}

Dapat dilihat bahwa ibu nifas yang melakukan senam nifas dengan pengeluaran lokia normal sebanyak 23 orang dan pengeluaran lokia yang melakukan senam nifas berkategori tidak normal sebanyak 9 orang. Uji statistik chi square dengan tingkat

\section{PEMBAHASAN}

Berdasarkan hasil penelitian diperoleh ibu nifas yang melakukan senam nifas sebanyak 32 orang. Ibu yang tidak mau melakukan senam nifas karena memiliki anggapan bahwa: setelah persalinan tidak boleh banyak melakukan gerakan-gerakan karena akan mengganggu pada penyembuhan setelah persalinan; setelah persalinan ibu nifas ingin cepat pulang, sehingga ibu nifas tinggal di klinik sangat terbatas waktunya meskipun bidan sudah mengupayakannya.

Pada umumnya lbu yang telah melahirkan dan melaksanakan senam nifas involusi uterusnya sebagian besar mengalami perubahan normal, meskipun masih ada yang mengalami sub involusi. Masih adanya ibu paska melahirkan yang mengalami sub involusi dikarenakan ibu nifas masih ada yang beranggapan bahwa ketika masa nifas tidak diperbolehkan mengkonsumsi ikan daging atau telur. Hal ini akan berdampak pada gizi ibu nifas padahal ikan, daging dan telur adalah sumber protein yang akan membantu mempercepat penyembuhan luka uterus tempat implantasi plasenta, sehingga berdampak terhadap involusi uterus.

Berdasarkan hasil penelitian bahwa pengeluaran lokia pada ibu yang melakukan senam nifas berkategori normal sebanyak 23 orang $(71,9 \%)$ dan yang tidak normal pengeluaran lokianya sebanyak 9 orang $(28,1 \%)$. Pengeluaran lokia yang melakukan ketelitian 0,05 menunjukkan nilai $\chi^{2}$ sebesar 6,125 dengan $\rho$ value sebesar $0,013<0,05$ artinya Ho ditolak dan $\mathrm{Ha}$ diterima. Hal ini menunjukkan ada pengaruh senam nifas terhadap pengeluaran lokia di wilayah Kerja Puskesmas Cilembang Kota Tasikmalaya.

senam nifas sebagian besar termasuk kategori normal berarti bahwa perubahan warna lokia sesuai dengan waku perubahannya. Selain kondisi tersebut pada penelitian ini ditemukan bahwa ibu nifas ada yang pengeluaran lokia tidak normal karena memiliki paritas lebih dari 4. Menurut Saefudin (2005) paritas merupakan salah satu faktor yang mempengaruhi proses involusi uterus dan pengeluaran lokia yang tidak normal.

Hasil analisis menunjukkan ada pengaruh senam nifas terhadap involusi uterus. Hal ini menunjukkan bahwa dengan senam hamil akan mempercepat pada proses persalinan. Senam nifas membantu mencegah pembentukan bekuan (thrombosis) pada pembuluh tungkai dan membantu kemajuan ibu dari ketergantungan peran sakit menjadi sehat dan tidak bergantung. Mengencangkan otot perut, liang senggama, otot-otot sekitar vagina maupun otot-otot dasar panggul (Anggriyana. 2010). Salah satu faktor yang mempengaruhi involusi uterus dan pengeluaran lokia adalah faktor mobilisasi dini. Berdasarkan pengamatan di Puskesmas Cilembang ibu yang melakukan senam nifas memiliki tenaga dan memiliki kebugaran yang lebih baik sehingga dapat meningkatkan mobilisasi pada diri ibu nifas, hal tersebut mempengaruhi pada involusi uterus. 
Hasil analisis menunjukkan ada pengaruh senam nifas terhadap pengeluaran lokia. Hal ini menunjukkan bahwa dengan senam hamil akan mempercepat pada proses persalinan. Adanya pengaruh senam nifas terhadap involusi uterus akan berdampak pula pada pengeluaran lokia. Menurut Maryunani (2011) dengan adanya involusi uterus, maka lapisan luar dari decidua yang mengelilingi situs plasenta akan menjadi nekrotik. Senam nifas adalah senam yang dilakukan untuk memperbaiki kembali organorgan yang mengalami perubahan selama kehamilan. Senam ini sebaiknya dilakukan dalam 24 jam pertama postpartum. Tujuan dari mobilisasi dini adalah untuk melancarkan sirkulasi, proses involusi, laktasi, dan mencegah komplikasi. Ada banyak manfaat yang dihasilkan dari senam nifas ini, jika

\section{KESIMPULAN}

Berdasarkan hasil analisa dan pembahasan mengenai pengaruh senam nifas terhadap involusi uterus dan pengeluaran lokia di wilayah Kerja Puskesmas Cilembang Kota Tasikmalaya Tahun 2015 dapat ditarik kesimpulan sebagai berikut: Pelaksanaan intervensi senam nifas di wilayah Kerja Puskesmas Cilembang Kota Tasikmalaya ini dilakukan pada 32 ibu nifas. Involusi uterus pada ibu yang melakukan senam nifas di wilayah Kerja Puskesmas Cilembang Kota Tasikmalaya terbanyak pada kategori normal sebanyak 24 orang (75\%).

\section{REFERENSI}

Ambarwati, E, \& Wulandari, D. (2008). Asuhan Kebidanan Nifas. Yogyakarta. Cendekia Press.

Arikunto, (2005). Manajemen Penelitian. Rineka Cipta : Jakarta

Anggriyana, (2010). Senam kesehatan. Nuha medika. Yogyakarta.

Bobak, (2004). Perawatan Maternitas dan Ginekologi. Edisi 4.Alih. Bahasa: Maria A.Wijayarini.Jakarta:EGC.

Brayshaw, E., (2007). Senam Hamil Dan Nifas. Jakarta : Buku Kedokteran EGC

Depkes RI, (2014). Profil Kesehatan Indonesia, Jakarta dilakukan secara teratur maka hasil yang diperoleh pun bisa maksimal (Bobak, 2005).

Berdasarkan hasil penelitian ini yang melakukan senam nifas memiliki kondisi tubuh semakin baik karena dengan melakukan senam nifas maka otot-otot polos, otot dasar panggul, otot liang sengggama dan sirkulasi darah menjadi teratur dan optimal sehingga memberikan dampak terhadap percepatan involusi uterus dan pengeluaran lokia. Seperti yang dikemukakan oleh Anggriana bahwa dengan melakukan senam nifas salah satu tujuannya adalah untuk mengencangkan otot perut, liang senggama, otot sekitar vagina, otot-otot dasar panggul, dan memperbaiki sirkulasi darah. Dengan melakukan senam nifas dapat mempercepat penyembuhan dan mencegah timbulnya komplikasi.

Pengeluaran lokia pada ibu yang melakukan senam nifas di wilayah Kerja Puskesmas Cilembang Kota Tasikmalaya terbanyak pada kategori normal sebanyak 23 orang $(71,9 \%)$. Ada pengaruh senam nifas terhadap involusi uterus di wilayah Kerja Puskesmas Cilembang Kota Tasikmalaya dengan $\rho$ value sebesar 0,005 $(<0,05)$. Ada pengaruh senam nifas terhadap pengeluaran lokia di wilayah Kerja Puskesmas Cilembang Kota Tasikmalaya $\rho$ value sebesar $0,013(<0,05)$.

Dinkes Jabar, (2014). Profil Kesehatan Jawa Barat, Bandung

Dinkes Kota Tasikmalaya, (2014). Profil Kesehatan Kota Tasikmalaya

Johan A Y, dan Tri, R., (2008). Senam Nifas Terhadap Involusi Pada Ibu Nifas. Jurnal Kesehatan

Manuaba, IBG., (2007). Konsep Obstetri dan Ginekologi Sosial Indonesia, EGC, Jakarta

Notoatmojo, (2005). Metodologi Penelitian Kesehatan. Jakarta : Rineka Cipta

PUSDIKNAKES, (2007). Buku Ajar Asuhan kebidana Pada Ibu Post Partum. 
Puskesmas Cilembang, (2014), Profil Kesehatan Puskesmas Cilembang Saifuddin, AB., (2005). Buku Acuan Nasional Pelayanan Kesehatan Maternal dan Neonatal . Jakarta: Yayasan Pustaka Sarwono Prawirohardjo

Sugiyono, (2006). Statistika Untuk Penelitian Bisnis. Alfabeta. Bandung.

Varney, (2007). Buku Ajar Asuhan Kebidanan, Volume 1, Jakarta, EGC
Wiknjosastro, (2009). IImu Kebidanan. Jakarta: Yayasan Bina Pustaka Sarwono Prawirohardja

Yuliani, T., (2009). Pengaruh Ambulasi Dini Terhadap Involusi Uterus di Klinik Bersalin Hadijah Medan, www. ui.ac.id diakses tanggal 6 Juli 2015

Yuswanto, A., (2008). Senam Nifas terhadap Involusi Uterus pada lbu Nifas, www. lideshare.net. diakses tanggal 6 Juli 2015. 